\title{
THE SOUTHERN ONTARIO OXIDANT STUDY (SONTOS): OVERVIEW AND CASE STUDIES FOR 1992
}

\author{
N. W. REID,* H. NIKI, $†$ D. HASTIE, $\uparrow$ P. SHEPSON,, P. ROUSSEL,$\ddagger$ O. MELO $\ddagger$

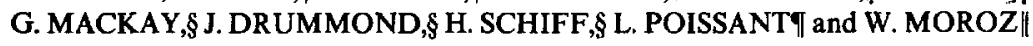 \\ * Ontario Ministry of Environment and Energy, Science \& Technology Branch, 2 St. Clair Avenue West, \\ 14th Floor, Toronto, Ont., Canada M4V 1L5; † Department of Chemistry/Centre for Atmospheric \\ Chemistry, York University, 4700 Keele Street, North York, Ont., Canada M3J 1P3; † Ontario Hydro \\ Technologies, 800 Kipling Avenue, Toronto, Ont., Canada M8Z 5\$4; §Unisearch Associates, Inc., 222 \\ Snidercroft Road, Concord, Ont., Canada L4K 1B5; \$Atmospheric Environment Service, Quebec Region, \\ 100 Blvd. Alexis Nihon, Saint Laurent, Quebec, Canada H4M 2N8; and \#W. Moroz Associates, RR \#2, \\ Hastings, Ont., Canada KOL 1 Y0
}

\begin{abstract}
Abatract - The southern Ontario oxidant study (SONTOS) is one of the scientific responses to the problem of ozone exceedences in the Windsor/Quebec City corridor, the strip extending from Windsor in the extreme southwest of Ontario, along the north shores of Lake Erie and Lake Ontario and down the St Lawrence valley. This corridor includes the two major metropolitan areas of Toronto and Montreal and experiences more exceedences of the Canadian ozone guideline per year than any other part of the country.

The overall objective of SONTOS is to elucidate the factors which lead to these high levels. The study design is based on intensive measurements made at a site to the NNW of Toronto, with supplementary measurements at other sites and on board an aircraft. This paper, and the seven which follow, describe and interpret the measurements made in the summer of 1992. Although this summer was noteworthy for generally very low ozone concentrations, a number of interesting observations have been made which have a bearing on the oxidant phenomenon in southern Ontario. In particular, this paper describes two specific events. In one, which occurred on 6 August 1992, the intensive measurement site experienced the impact of a polluted air mass, which had apparently travelled to the site from Toronto, by way of Lake Ontario. This case has been contrasted with an event in the last week of August, in which large-scale, organised southwesterly flow led to the conditions which more typically give rise to widespread ozone episodes in the province. Events similar to the 6 August episode occurred on several occasions during the study period, and underline the very important role of the Great Lakes in ozone transport and delivery in southern Ontario. Copyright (C) 1996 Elsevier Science Ltd
\end{abstract}

Key word index: Ozone, oxidants, Ontario, transport, photochemistry.

\section{INTRODUCTION}

The Canadian ozone guideline value, expressed as the maximum acceptable 1 - $h$ average is $82 \mathrm{ppb}$. This concentration is generally exceeded a number of times each summer in various parts of the country. The number of exceedences, of course, varies widely from year to year, depending on the meteorological conditions of the year. Concern over elevated ambient ozone concentrations has led to the development of a management plan (CCME, 1990) for oxides of nitrogen $\left(\mathrm{NO}_{x}\right)$ and volatile organic compounds (VOC), particularly in the three designated non-attainment areas:

- the Lower Fraser Valley in British Columbia, including the Vancouver metropolitan area,

- the Windsor/Quebec City corridor, encompassing southern Ontario and the St Lawrence Valley, and including Toronto and Montreal, and
- the South Atlantic Region of the maritime provinces on the Canadian east coast.

A number of scientific investigations related to the formation of tropospheric ozone are being conducted in conjunction with the management plan. In particular, the Canadian Institute for Research in Atmospheric Chemistry has developed an oxidants research plan (CIRAC, 1990). The southern Ontario oxidant study (SONTOS; Reid et al., 1993) is a component of this research plan. The overall objective of SONTOS is to elucidate the factors resulting in the formation of elevated concentrations of tropospheric ozone in southern Ontario. To achieve this objective, SONTOS was designed to include the investigation of both transport and photochemical formation of ozone and/or its precursors. The major effort in SONTOS to date has been devoted to two intensive field measurement campaigns. Subsequent work will involve inte- 
gration of field data with models to improve both the modelling of oxidant production in southern Ontario, and the interpretation and understanding of the data.

SONTOS is a collaborative venture between a number of investigators, as will be detailed in the measurements section. This collaboration has led to seven papers describing different facets of the work Five of these papers follow; the seventh is published elsewhere (O'Brien et al., 1995). The purpose of this paper is to provide an overview of the field measurements, with a description of two case studies from the 1992 campaign.

DESCRIPTION OF MEASUREMENTS

The SONTOS intensive measurement site was located in a rural area near the town of Hastings, Ontario, about $140 \mathrm{~km} \mathrm{NNE}$ of Toronto (Fig. 1). The site itself was about $8 \mathrm{~km} \mathrm{NE}$ of Hastings (population 1000 ), and was in an open, grassed field, elevated by about $40 \mathrm{~m}$ above the Trent River which is about $300 \mathrm{~m}$ to the north of the site. The surrounding area is predominantly agricultural.

Typically, ozone events in southern Ontario occur with southwesterly flow. Under these conditions, Hastings lies downwind of Toronto. Supplementary measurements were made at a site near Binbrook (see Fig. 1), which is upwind of Toronto under the same conditions, lying about $40 \mathrm{~km}$ to the $\mathrm{SW}$ of the metro- politan area. The Binbrook site is flat and open, also in an agricultural area. To provide further information on pollutant concentrations upwind, as well as aloft, selected measurements were made on board an aircraft. The 1992 field campaign lasted from 15 July to 31 August. The species measured included:

- precursors (e.g. speciated hydrocarbons, $\mathrm{NO}_{x}$ )

- intermediates (e.g. formaldehyde, peroxy radicals), and

- products (e.g. ozone and a number of odd-nitrogen species, including $\mathrm{HNO}_{3}$, particulate nitrate, PAN, and organic nitrates).

Continuous measurements at Hastings were made of ozone, sulphur dioxide and $\mathrm{NO} / \mathrm{NO}_{2} / \mathrm{NO}_{x}$, using commercially available instruments. The concentrations of $\mathrm{NO}$ and $\mathrm{NO}_{2}$ were also measured using a high-sensitivity analyser with photolytic $\mathrm{NO}_{2}$ conversion (Tecan, Inc.). Measurements of $\mathrm{NO}_{y}$ were made using a chemiluminescent instrument fitted with a molybdenum catalyst (Hastie et al., 1995). A tunable diode laser absorption spectrometer was used to determine hydrogen peroxide and formaldehyde, while PAN measurements were made using an automated GC system with electron capture detection. Hydrocarbon samples were collected in stainless steel canisters for subsequent $\mathrm{GC}$ analysis, and organic nitrates on charcoal, also for subsequent analysis, while carbonyl compounds were determined by the

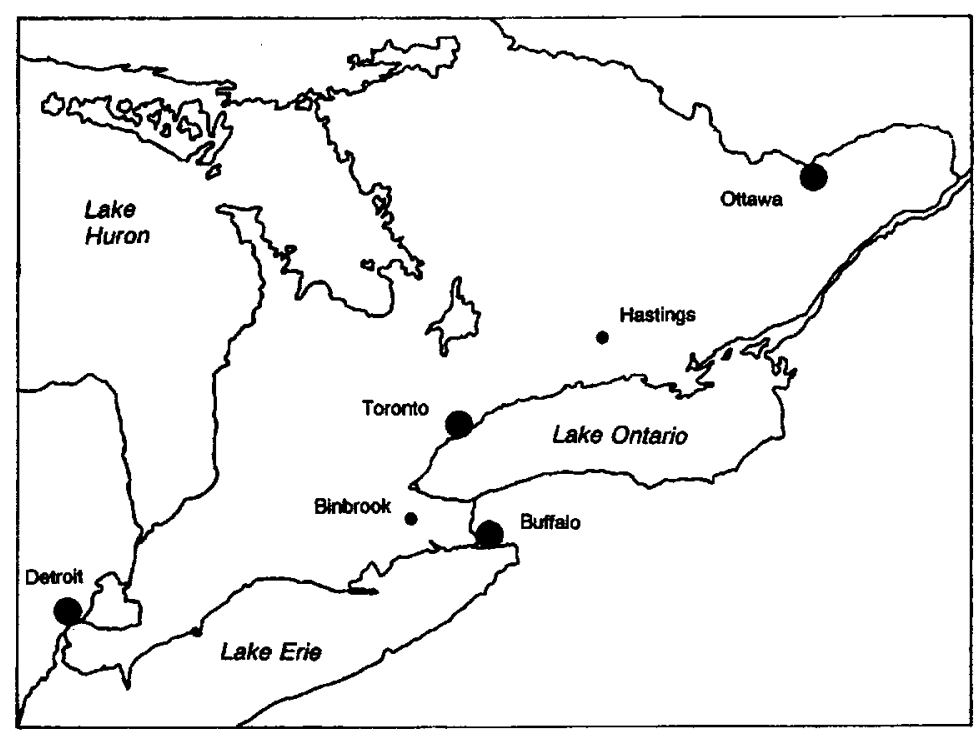

Fig. 1. Map of southern Ontario, showing site locations. 
DNPH/HPLC method. A radical amplifier system was operated to determine the concentrations of pero$x y$ radicals. Further details of these measurements are provided in the papers which follow this (Roussel $e t$ al., 1995; Hastie et al., 1995; Shepson et al., 1995; Niki, et al., 1995; Arias et al., 1995). An automated filter pack system was operated, following the protocols of the APIOS acid deposition monitoring network (Chan et al., 1985) to provide concentrations of particulate nitrate and vapour-phase nitric acid.

Meteorological measurements (wind speed and direction, temperature and relative humidity) were made on a $10 \mathrm{~m}$ tower on the site, and on a secondary tower located about $500 \mathrm{~m}$ away at a lower elevation. The purpose of the secondary tower was to allow an assessment of the local topography on the wind speed and direction (Roussel et al., 1995). The vertical structure of the atmosphere was also determined using an acoustic sounder supplemented by minisonde flights.

The parameters measured at Binbrook were $\mathrm{NO}_{x}$ ozone, and hydrocarbons, plus meteorological parameters. The methods were as described above. The same set of measurements was carried out on board the aircraft, with canister sampling for hydrocarbons, and rapid response, high-sensitivity instruments manufactured by Unisearch Inc. for ozone and $\mathrm{NO}_{x}$.

The measurements are summarised in Table 1 , which also indicates the principal investigators associated with each measurement. Additional data were available from the Provincial Air Quality network.

\section{RESULTS}

The summer of 1992 was unusually cool and cloudy, and ozone concentrations at Hastings exceeded 80 ppb on only three days $(23,25$ and 26 August), in contrast with 1993, when this level was exceeded eight times during the corresponding summer period. Nevertheless, a number of scientifically interesting cases occurred; data from two time periods will be presented here as case studies.

\section{August 1992}

The 6th of August was generally bright and sunny, with $3 \mathrm{~m} \mathrm{~s}^{-1}$ winds from the west during most of the day. The temperature reached a maximum of $25^{\circ} \mathrm{C}$ between 4 and 5 p.m. The ozone record for 6 August 1992 shows that a very sharp increase in concentration occurred over a period of a few minutes at about 5.30 p.m. The change in concentration was about $22 \mathrm{ppb}$, from 44 to $66 \mathrm{ppb}$ (Fig. 2), and was accompanied by abrupt changes in the concentrations of most other chemical species monitored at the site. In particular, the $\mathrm{NO}_{x}$ concentration increased from 0.5 to $4 \mathrm{ppb}$ at this time. Although not included in Fig. 2, the concentration of tetrachloroethene (which is determined in the course of PAN measurements) also increased sharply at the same time.

The increases in concentration shown in Fig. 2 are clearly not the result of local photochemistry. The rate of change is too rapid, the time of day at which it

Table 1. Measurements carried out during the summer 1992 filed study

\begin{tabular}{|c|c|c|}
\hline Parameter & Technique & Investigator \\
\hline \multicolumn{3}{|l|}{ Hastings } \\
\hline $\mathrm{NO}, \mathrm{NO}_{2}, \mathrm{NO}_{x} \mathrm{NO}_{y}$ & Chemiluminescence & Several \\
\hline $\begin{array}{l}\text { Ozone } \\
\text { PAN }\end{array}$ & $\begin{array}{l}\text { UV absorption } \\
\text { Automated GC }\end{array}$ & $\begin{array}{l}\text { Several } \\
\text { P. Shepson, York Univ. }\end{array}$ \\
\hline Carbonyls & DNPH/LC & P. Shepson, York Univ. \\
\hline Organic nitrates & Charcoal tube/GC & P. Shepson, York Univ. \\
\hline Peroxy radicals. & Radical amplifier & D. Hastie, York Univ. \\
\hline Hydrogen peroxide & Tunable diode laser & D. Hastie, York Univ. \\
\hline Formaldehyde & Tunable diode laser & D. Hastie, York Univ. \\
\hline Hydrocarbons $\left(C_{2}\right.$ to $\left.C_{10}\right)$ & Canister, GC/FID & H. Niki, York Univ. \\
\hline $\begin{array}{l}\mathrm{SO}_{2,}, \mathrm{SO}_{4}^{2-}, \mathrm{NO}_{3}^{-}, \mathrm{HNO}_{3} \\
\text { lac }\end{array}$ & $\begin{array}{l}\text { Filter pack } \\
\text { Automated GC }\end{array}$ & $\begin{array}{l}\text { Ontario Min. of Env. } \\
\text { L. Poissant, AES }\end{array}$ \\
\hline $\begin{array}{l}\text { Meteorology (wind } \\
\text { speed, direction, } \\
\text { temperature, } \mathbf{R H} \text { ) }\end{array}$ & Met. tower $(\times 2)$ & $\begin{array}{l}\text { P. Roussel, Ontario } \\
\text { Hydro }\end{array}$ \\
\hline Vertical profiles & Acoustic sounder & $\begin{array}{l}\text { P. Roussel, Ontario } \\
\text { Hydro }\end{array}$ \\
\hline \multicolumn{3}{|l|}{ Binbrook } \\
\hline $\mathrm{NO}, \mathrm{NO}_{2}, \mathrm{NO}_{x}$ & Chemoluminescence & $\begin{array}{l}\text { P. Roussel, Ontario } \\
\text { Hydro }\end{array}$ \\
\hline Ozone & UV absorption & $\begin{array}{l}\text { P. Roussel, Ontario } \\
\text { Hydro }\end{array}$ \\
\hline Hydrocarbons $\left(C_{2}\right.$ to $\left.C_{10}\right)$ & Canister, GC/FID & H. Niki, York Univ. \\
\hline $\begin{array}{l}\text { Aircraft } \\
\text { NO, } \mathrm{NO}_{2}, \mathrm{NO}_{x}, \mathrm{O}_{3}\end{array}$ & Luminox & $\begin{array}{l}\text { G. Mackary/H. Schiff, } \\
\text { Unisearch }\end{array}$ \\
\hline Hydrocarbons $\left(C_{2}\right.$ to $\left.C_{10}\right)$ & Canister, GC/FID & H. Niki, York Univ. \\
\hline
\end{tabular}




\section{Concentrations at Hastings: 6 August 1992}

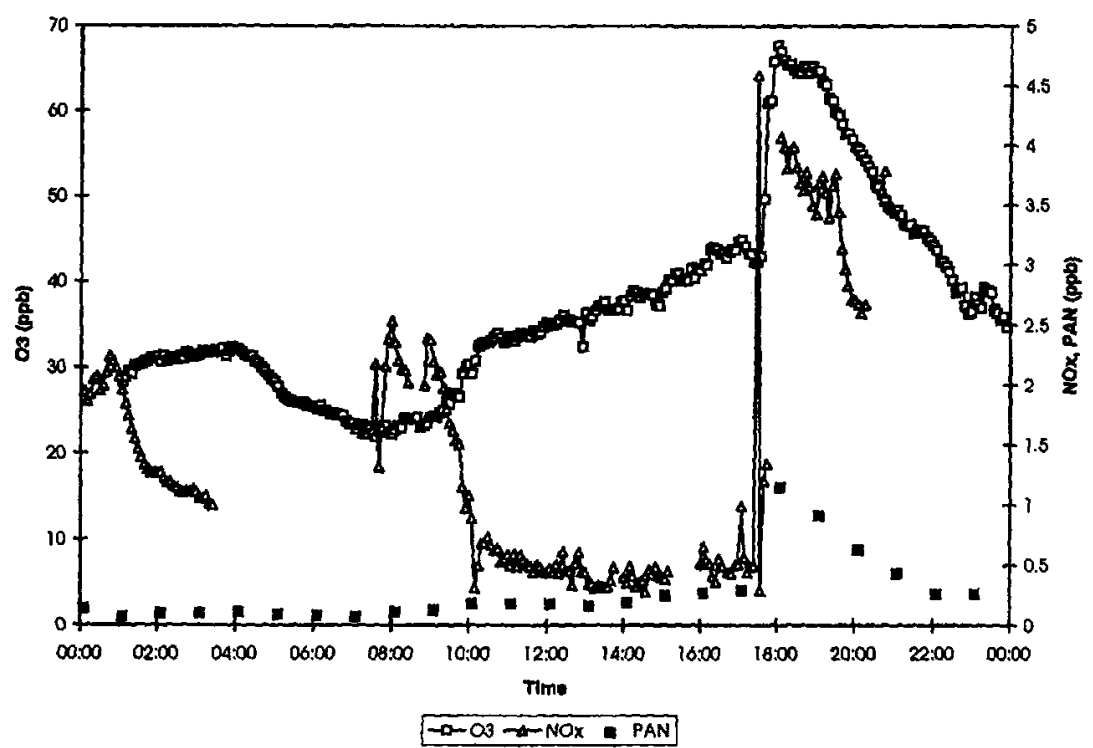

Fig. 2. Concentrations of ozone, $\mathrm{NO}_{x}$ and PAN for Hastings for 6 August 1992.

occurred is wrong, and, most important, tetrachloroethene is not a photochemical product. It is, in fact, a good tracer of anthropogenic activity, being used extensively in dry cleaning and in various industrial processes as a degreasing solvent. It therefore follows that at about 5.30 p.m. on 6 August 1992, the site came under the impact of an urban-influenced air mass, with the transition being quite abrupt.

The meteorological data presented in Fig. 3 provide confirmation of this supposition. Concurrent with the increase in pollutant concentrations there was a $2^{\circ} \mathrm{C}$ drop in temperature, and an increase in relative humidity from 30 to $46 \%$. At the same time the wind direction changed from westerly to southwesterly.

The interpretation placed upon this information is that the wind shift which occurred at the site of 5.30 p.m., brought with it a more polluted air mass, which had travelled for some time over Lake Ontario. This conclusion is supported by the wind direction, and by the observation of a slight decrease in temperature coupled with a substantial increase in relative humidity. The most likely origin for the pollutants measured in this air mass is Toronto, as suggested by the following observations.

(i) The concentration of $\mathrm{SO}_{2}$ was observed to increase along with the other pollutants, but the increase was relatively small (from about 2 to $5 \mathrm{ppb}$ ). Toronto is a major urban centre, but has relatively few $\mathrm{SO}_{2}$ emission sources.

(ii) The more polluted air mass appears to be less "aged" or processed, as is shown by a plot of $\left.\left(\mathrm{NO}_{y}\right]-\left[\mathrm{NO}_{x}\right]\right) /\left[\mathrm{NO}_{x}\right]$ as a function of time
(Fig. 4). This quantity measures the relative amount of odd nitrogen which has been converted to more oxidised forms, and is therefore a measure of the extent to which the air parcel has been processed. The plot is somewhat noisy, as is to be expected from the nature of the difference that is involved in the ratio. However, the ratio was generally low overnight as is to be expected, since there will be little processing occurring in the absence of sunlight. Following sunrise, with the onset of vertical mixing and photochemical activity in the atmosphere, the ratio increased, with a subsequent significant decrease at the time of the increases in ozone and other measured species. Toronto is the closest major source area to Hastings, with significant emissions of ozone precursors, as well as tracer species such as tetrachloroethene.

To support further the inference regarding the origin of this air mass, forward trajectories from the Toronto airport were also plotted (Fig. 5). These are surface geostrophic trajectories (Kurtz et al., 1984). Although the timing of the shifts in the trajectories does not match exactly with the timing of the concentration changes seen at Hastings, the following points are clear.

(i) All trajectories for 6 August 1992 left Toronto, and travelled initially over Lake Ontario.

(ii) During the early part of the day the trajectories indicate that air parcels from Toronto travelled almost due east. 


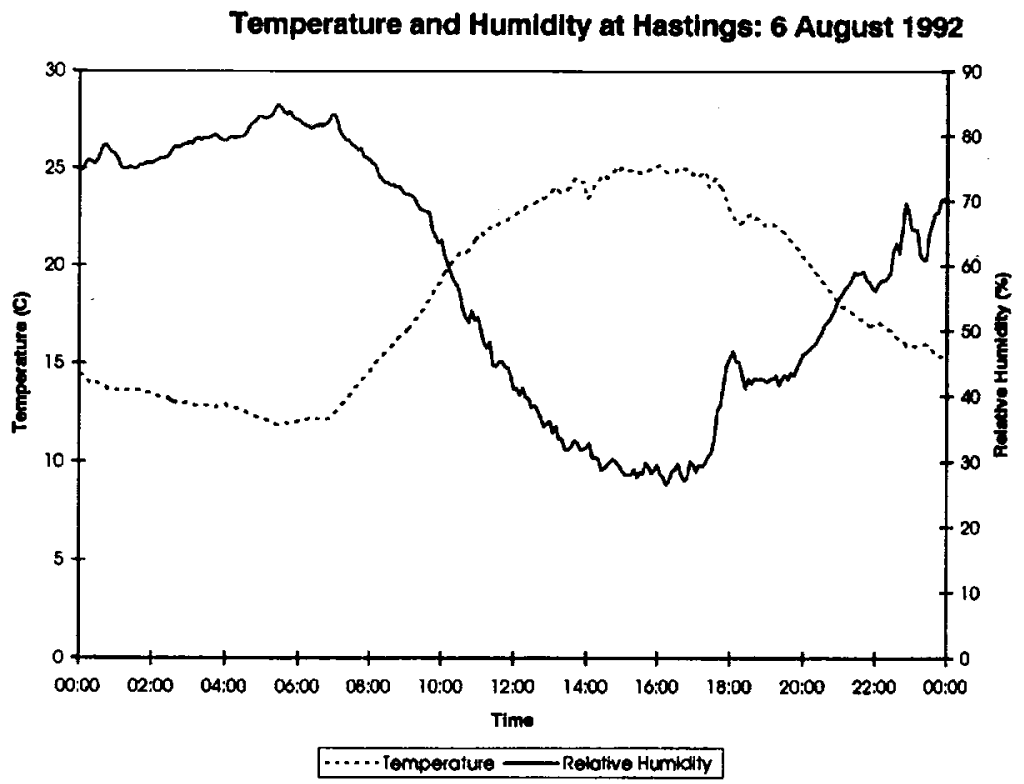

Fig. 3. Temperature and relative humidity for Hastings for 6 August 1992.

NOz/NOX at Hastings: 6 August 1992

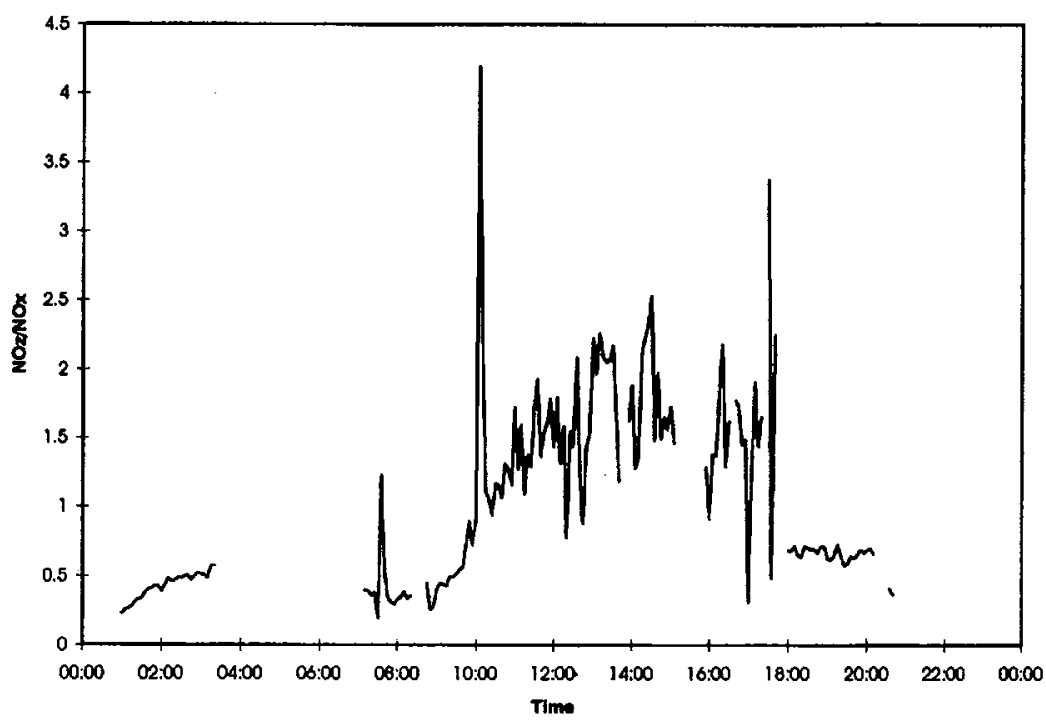

Fig. 4. The ratio $\left[\mathrm{NO}_{z}\right] /\left[\mathrm{NO}_{x}\right]$ for Hastings for 6 August $1992\left(\left[\mathrm{NO}_{2}\right]=\left[\mathrm{NO}_{y}\right]-\left[\mathrm{NO}_{x}\right]\right)$.

(iii) Later in the day the trajectories curved to the north, coming ashore to the east of Toronto. At some time during the afternoon the trajectory would have passed directly over Hastings. The corresponding travel time would have been about $12 \mathrm{~h}$
To summarise the above, an abrupt increase in pollutant concentration was observed at the Hastings site on the afternoon of 6 August 1992. The available evidence is consistent with the interpretation that prior to this time the site was under the influence of 


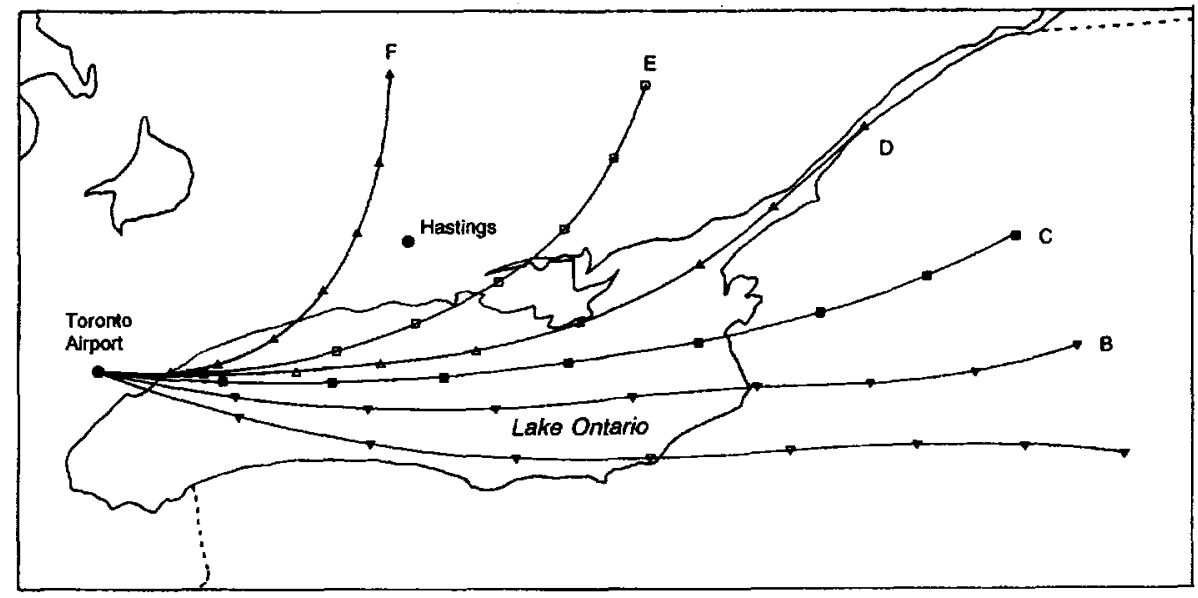

Fig. 5. Forward trajectories from Toronto International Airport for 6 August 1992 (3-h time steps, start times: (A) midnight, (B) 3 a.m., (C) 6 a.m., (D) 9 a.m., (E) noon, (F) 3 p.m.)

a relatively clean, but "well-aged" air mass. After the increase, the air mass impacting the site was much "younger" or less processed, but more polluted. This air mass appears to have passed over Toronto approximately $12 \mathrm{~h}$ before reaching Hastings (i.e. some time in the early morning), with subsequent travel over Lake Ontario. It then turned north, travelling about $30 \mathrm{~km}$ over land before reaching Hastings.

This case has been investigated further in two modelling studies (Lin et al., 1995; McConnell et al., 1995). Abrupt increases in the concentrations of ozone and related species are relatively common at the Hastings site, and were observed on 15 to 20 days in each of the summers of 1992 and 1993.

\section{2/23 August 1992}

Towards the end of August 1992 an episode of relatively high ozone concentration occurred. This case came closer to a "traditional" episode for southwestern Ontario than occurred during the rest of the summer, and is presented as a contrast to the previous one. Ozone episodes in southern Ontario typically occur under conditions of southwesterly flow, usually at the back of a high-pressure system (Heidorn and Yap, 1986). Under these conditions long-range transport of ozone and/or precursors occurs, adding to local emissions, leading to the occurrence of elevated concentrations over a wide area (Yap et al., 1988). The case of 6 August 1992, as discussed above, is very different, and the ozone peak observed at Hastings on this day apparently had a local (i.e. within Ontario) origin.

The weather maps for 22 August 1992 showed a large area of high-pressure stretching from James Bay in the north to Virginia in the south. This high remained essentially stationary throughout the day.
A few scattered clouds occurred, and temperatures were generally in the mid-twenties (Celsius). Ozone concentrations reached $70-75 \mathrm{ppb}$.

On the following day (23 August), the high-pressure area moved out to the east, giving a classical "back of the high" situation over southern Ontario, with $S$ to SW flow (Fig. 6). Skies were clear, and the maximum temperature approached $30^{\circ} \mathrm{C}$ at a number of sites. These conditions are generally conducive to the production of ozone in the region, and levels of about $80 \mathrm{ppb}$ were observed at several stations.

The ozone record for 23 August for Hastings is shown in Fig. 7. The peak concentration was $84 \mathrm{ppb}$, barely exceeding the Canadian guideline value. The peak occurred between 7 and 8 p.m., suggesting that this was ozone produced elsewhere, and transported to Hastings. The concentration of $\mathrm{NO}_{x}$ also peaked (at $7 \mathrm{ppb}$ ) late in the evening. During daylight hours on 23 August the $\mathrm{NO}_{x}$ concentration was fairly steady between 4 and $5 \mathrm{ppb}$. These concentrations should be compared with those measured for 6 August, when the $\mathrm{NO}_{x}$ concentration was of the order of $0.5 \mathrm{ppb}$, until the more polluted air mass arrived at the site, when it increased to $4 \mathrm{ppb}$.

It is interesting to note that the peak concentration of $\mathrm{SO}_{2}$ was about $15 \mathrm{ppb}$, substantially higher than was observed on 6 August. This is characteristic of regional scale episodes in southern Ontario, when significant contributions are experienced from coal burning power plants to the southwest. These high observed $\mathrm{SO}_{2}$ concentrations at Hastings on 23 August indicated a polluted air mass. The nitric acid and particulate nitrate levels measured in Ontario were also high, lying in the top $2.5 \%$ of their values for the year at a number of sites (data from the CAPMoN monitoring network; Vet, 1993). This confirms that 


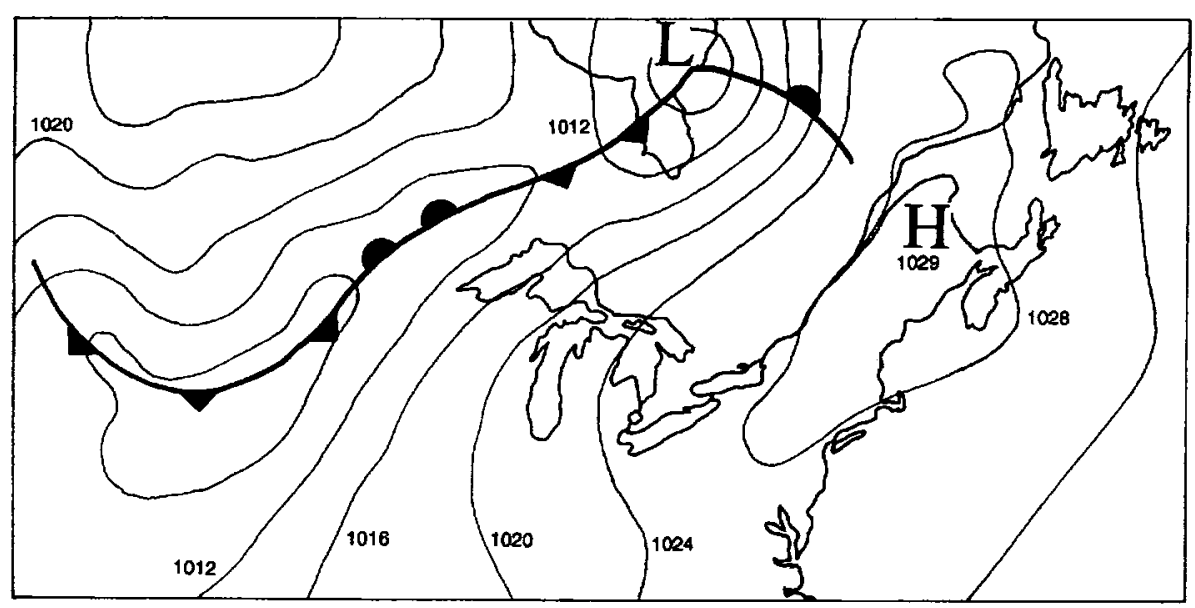

Fig. 6. Synoptic weather map for eastern North America for 23 August 1992.

Concentrations at Hastings: 23 August 1992

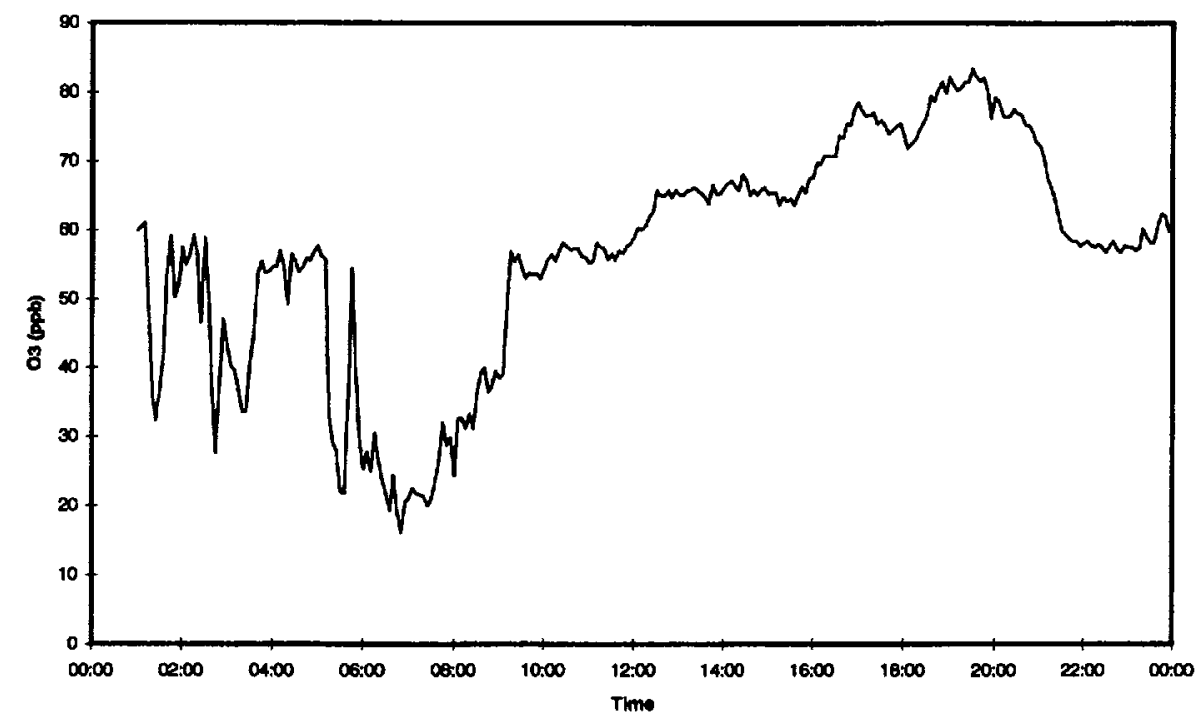

Fig. 7. Ozone record for Hastings for 23 August 1992.

considerable photochemical activity took place in the air mass, but it was not reflected in the observed ozone concentrations, either at the Hastings site, upwind or on board the aircraft. The maximum groundlevel ozone concentration at upwind sites on $23 \mathrm{Au}$ gust was $80 \mathrm{ppb}$, while a maximum of $110 \mathrm{ppb}$ was recorded on board the aircraft while passing through a narrow plume. During the remainder of the flight the measured concentration ranged between 60 and $90 \mathrm{ppb}$. The maximum PAN concentration measured at Hastings on 23 August was also relatively low, at 1.1 $\mathrm{ppb}$. These observations raise the question as to why the oxidant levels were not any higher.

Possible reasons include the following:

- The SW flow did not persist long enough for a regional scale ozone episode to occur. 
- Because the summer of 1992 was significantly cooler than normal, ambient isoprene concentrations were lower than normal.

The median isoprene concentration for the summer of 1992 was about $0.08 \mathrm{ppb}$, significantly lower than the corresponding value of $0.13 \mathrm{ppb}$ for 1991 (Niki, 1995). However, the concentrations on 22 and 23 August were relatively high, of the order of $2-3 \mathrm{ppb}$, consistent with the fairly high temperatures experienced on these days. It therefore seems most reasonable to assume that higher oxidant levels would have developed if the appropriate flow patterns had persisted.

\section{SUMMARY OF HASTINGS RESULTS}

A preliminary study (Roussel and Moroz, 1992) indicated that the site at Hastings is regionally representative. This finding has been confirmed in an analysis reported by Hastie et al. (1995). These authors confirmed findings from SONTOS and a number of earlier studies (e.g. Heidorn and Yap, 1986) that highest pollutant levels occur in southern Ontario under conditions of southwesterly flow. The present work confirms these expectations, but analysis of the event which occurred on 6 August 1992 also indicated that significant local (i.e. within Ontario) production of ozone can occur. Abrupt increases in the concentration of ozone and other species were observed on a number of days during the study period, emphasising the importance of transport over or along the Great Lakes.

Details of production of ozone in Ontario, and its transport to the Hastings site were further investigated in two modelling studies (Lin et al., 1995; McConnell et al., 1995). Detailed interpretation of the measurements made at the Hastings and Binbrook sites can be found in the descriptions by Roussel et al. (1995) and Shepson et al. (1995). A tie in between SONTOS data and urban emissions, particularly those from automobile sources has also been made (McLaren et al., 1995).

Acknowledgements-Grateful acknowledgement is made to CIRAC, under whose coordination this project took place, and to the Ontario Ministry of Environment and Energy, Ontario Hydro, Consumers Gas, Imperial Oil and Dow Chemical who provided financial support. This is CIRAC Publication Number $94-1$.

\section{REFERENCES}

CCME (1990) Management plan for nitrogen oxides ( $\mathrm{NO}_{x}$ ) and volatile organic compounds (VOC). Canadian Council of Ministers of the Environment, November 1990.
CIRAC (1990), A plan for a Canadian oxidants research program (CORP). Canadian Institute for Research in Atmospheric Chemistry, December 1990.

Chan W. H., Orr D, B. and Vet R. J. (1985) Acidic precipitation in Ontario study, an overview: the event wet/dry deposition network (1st Revised Edition). Report ARB142-85-AQM APIOS-025-85.

Hastie D. R., Shepson P. B., Roussel P., Lazlo S. and Melo $\mathrm{O}$ (1995) Summertime $\mathrm{NO}_{2}, \mathrm{NO}_{y}$ and ozone at a site in rural Ontario Atmospheric Environment 30, 2157-2165.

Heidorn K, and Yap D. (1986) A synoptic climatology for surface ozone concentrations in southern Ontario, 1976-1981. Atmospheric Environment 20, 695.

Kurtz J., Tang A. J. S., Kirk R and Chan W.H. (1984) Analysis of an acidic deposition episode at Dorset, Ontario. Atmospheric Environment 18, 387-394.

Lin X., Roussel P. B., Taylor R., Melo O., Shepson P. B., Hastie D. R, and Niki H. (1995) Impacts of Toronto urban emissions on ozone kevels downwind - a case study. Atmospheric Environment 30, 2177-2193.

McConnell J., Plummer D. Shepson P., Hastie D. and Niki H. (1995) Modelling of ozone formation at a rural site in southern Ontario. Atmospheric Environment 30, 2195-2217.

McLaren R., Singleton D. L., Lai J., Wu Z. and Niki H (1995) Analysis of emission sources contributing to ambient hydrocarbon distributions measured at urban sites in Toronto. Atmospheric Environment 30, 2219-2235.

Niki H. (1995) Personal communication.

O'Brien J. M., Shepson P. B., Muthuramu K., Hao C., Niki H., Taylor R. and Roussel P. B. (1995) Measurements of alkyl and multifunctional organic nitrates at Hastings, Ont. during the southern Ontario oxidant study (SONTOS) 1992. J. Geophys. Res. (accepted)

Reid N. W., Niki H., Hastie D., Shepson P., Roussel P., Melo O., Mackay G., Schiff H. and Poissant L. (1993) The Hastings, Ontario, Atmospheric Chemistry Study. Presented at the 86th Annual Meeting of the Air and Waste Management Association, Denver, Colorado, June 1993.

Roussel P. and Moroz W. J. (1992) Oxidant monitoring in southern Ontario: the suitability of a site near Hastings, Ontario, as a rural monitoring station within the Windsor-Quebec city corridor. Ontario Hydro Research Division Report 92-109-K

Roussel P. B., Lin X, Camacho F., Laszlo S., Taylor R. Melo O. and Niki $H$. (1995) Observation of $\mathrm{O}_{3}$ and precursor levels at two sites around Toronto, Ontario, during the Summer of 1992. Atmospheric Environment 30, 2145-2156.

Shepson P. B., O'Brein J. M., Muthuramu K., Hao C., Niki H., Taylor R. and Roussel P. (1995) Measurements of multifunctional organic nitrates and their contribution to NO, during the southern Ontario oxjdant study (SONTOS). Atmospheric Environment 30, 2177-2193.

Vet R. J. (1993) Personal communication.

Yap D., Ning D. T. and Dong W. (1988) An assessment of source contributions to the ozone concentrations in south ern Ontario, 1979-1985. Atmospheric Environment 22. 1161. 